work has been carried out on the novel form of distillation, which was invented by the Division, arrangements having been made for the manufacture of the gauze packing. Research on plastic casein has also been undertaken and research on the preparation and properties of carbon black from waste gases from the pyrolysis of natural gas has been concluded, while further work has been carried out on the preparation of carbon black by the channel process. Work on the use of formalin for the disinfection of seed wheat has been extended to include the study of many organic compounds as seed disinfectants. Good progress is reported in work on the fundamental laundrying operation bleaching, as well as in work on the fading of dyed textiles in sunlight, determination of damage to silk by a viscosity method and the regain of raw wool.

In the Division of Mechanical Engineering, the Aerodynamic Laboratory has carried out tests on models of three service aircraft in the wind tunnel to prove the accuracy of prediction of the performance of aircraft from the results of wind tunnel tests. Comprehensive wind tunnel tests have also been made for a Canadian aircraft building firm in connexion with the development of an aeroplane being designed specifically for commercial service in Canada. Measurement of hydrodynamic forces on stop logs for emergency dams in ship canals was a new and interesting study commenced during the year. Other problems under investigation include the work on fire hazard testing, farm windmills, gasolene specifications, aireraft instruments and the inspection and labelling of oil burners. The Division of Physics and Electrical Engineering has undertaken fundamental work on light, sound, heat and electricity as well as standardization in these and in related fields. The development of an improved and highly satisfactory means of heating refrigerator cars in winter which makes it possible to maintain uniform temperatures in the cars is now being taken up com. mercially. Studies in heat transfer are being applied to the tests in insulating material and to the investigation of heat conservation qualities of textiles used for clothing. Tests are also being made to determine the sound absorptive properties of building materials and the proper design of rooms for the best acoustical effects. Other experiments have been concerned with electrical methods of packing poultry in preparation for marketing. A second cathode-ray direction finder was built during the summer, and a development programme to adapt this type of radio direction finder to commercial service has been undertaken.

In addition to the work of the various Divisions, important work has been carried out through the joint or associate committees, including research on the breeding of rapid growing rust-resistant strains of wheat, oil seeds research, feeding-stuffs research, investigations on seed treatment with formaldehyde, on the effect of environmental factors on wool, on deficiency diseases of sheep, on asbestos, etc. The Associate Committee of Parasitology has been responsible for studies of liver fluke disease, warble fly eradication, anthelmintics, etc.

\title{
Explorations of the Smithsonian Institution, I937
}

$\mathrm{I}^{\mathrm{N}}$ the annual review of the research activities in the field of the Smithsonian Institution, Washington, D.C. ("Explorations and Field-Work of the Smithsonian Institution in 1937". Pp. 122), a preliminary announcement is made of the results of twenty-four expeditions, for the most part in geology, biology and anthropology. Some of these were financed wholly by the Institution, others were cooperative undertakings with institutions interested in the promotion of these respective branches of science. Most of the expeditions in 1937 were within the American continent, including the West Indies. Of the expeditions to other continental areas, Mr. H. G. Deignan describes an exploring expedition to Siam for the purpose of observing and collecting specimens of the fauna.

An expedition to the East Indies in conjunction with the National Geographic Society led by Dr. W. M. Mann visited Sumatra, Amboina, the New Guinea coast, Java, and Singapore, collecting living animals, birds and reptiles for the National Zoological Park. The minerals of Russia were investigated by Mr. E. P. Henderson, who visited the Kola Peninsula before attending the International Geological Congress at Moscow. The American expeditions and investigations included catching walrus pups in Greenland and moose hunting in Alaska, collecting insects in the West Indies and Virginia, fossils in Michigan, Utah, Arizona and elsewhere, and studies of the Montagnais-Naskapi Indians of the St. Lawrence river. Among the archæological investigations an account is given by Mr. David I. Bushnell, jun., of an ancient site on the banks of the Rapahannock in Virginia, exposed by flood water in the early months of 1937 , which produced stone implements of varied types and pottery bearing the impression of coiled backetry, considered to be the oldest form of pottery found in the Rapahannock valley. Other village sites of a similar character, and exposed by the same agency, were visited, which suggest that much instructive evidence would be obtained by systematic excavation. Further investigations on the Lindenmeier stone age habitation site in northern Colorado have produced evidence of importance relating to Folsom man, though the skeletal remains of this early type of man in America still evade search. Dr. F. H. H. Roberts, jun., who describes the results of his investigations here in 1937, records the discovery of a number of anvil stones still in situ, on which Folsom man manufactured his implements and cracked bones for marrow, as is shown by the fragments of various kinds of stone and bone found in the surrounding ground. The stratified deposits show that the site was occupied after the climax of the Wisconsin period, but within the late Glacial, when a colder and moister climate, which was responsible for the heavy soil zone overlying the evidence of occupation, was approaching. Dr. Aleš Hrdlička adds details relating to his investigations in the Aleutian islands of the problem of the migration of early man into America further to those already reported (see NATURE, 140, 577). 